\title{
Accessory Tissue
}

National Cancer Institute

\section{Source}

National Cancer Institute. Accessory Tissue. NCI Thesaurus. Code C120859.

A supernumerary tissue in addition to normal tissues. 